\title{
Black pine (Pinus nigra Arn.) growth divergence along a latitudinal gradient in Western Mediterranean mountains
}

\author{
Darío MARTín-BENITO*, Miren del Río, Isabel CAÑELlas \\ Centre for Forest Research, CIFOR-INIA, Ctra. La Coruña, km 7.5. 28040 Madrid, Spain
}

(Received 9 June 2009; accepted 5 September 2009)

Keywords: growth trends / climate change / dendroecology / Pinus nigra / drought stress

\begin{abstract}
- Most studies of tree-growth and climate report positive responses to global warming in high latitudes and negative responses at lower ones.

- We analyzed tree-ring width of Pinus nigra Arn. along a $500 \mathrm{~km}$ latitudinal transect in the Iberian Peninsula to study the temporal trend and climate forcing in tree radial growth during the last century. - Tree growth was enhanced by cool summers and moist cold seasons. Increased moisture stress has decreased tree growth rates. However, we present evidence of growth increases in some trees in all sampled populations after 1980's. Climate change negatively (positively) affected between $72 \%$ (5\%) of trees in the southern populations and $40 \%(25 \%)$ in the north Trees with positive growth trends were favored by winter temperatures and their abundance was inversely correlated with forest productivity.

- Our findings add evidences of tree growth divergence in the Mediterranean basin and show the gradual transition between forests where positive (temperate and boreal) and negative (Mediterranean) growth trends dominate.
\end{abstract}

Résumé - Écarts de croissance chez le pin noir (Pinus nigra Arn.) le long d'un gradient latitudinal dans les montagnes de l'Ouest méditerranéen.

- La plupart des études sur la croissance de l'arbre en relation avec le climat rapportent des réponses positives au réchauffement climatique dans les hautes latitudes et des réponses négatives dans les basses latitudes.

- Pour étudier l'évolution temporelle et le forçage climatique dans la croissance radiale des arbres au cours du siècle dernier, nous avons analysé la largeur des cernes chez Pinus nigra Arn. le long d'un transect latitudinal de $500 \mathrm{~km}$ dans la Péninsule Ibérique.

- La croissance des arbres a été augmentée par des étés frais et des saisons froides humides. L'augmentation du stress hydrique a diminué les taux de croissance des arbres. Cependant, nous présentons la preuve de l'augmentation de la croissance de certains arbres dans toutes les populations échantillonnées après 1980. Le changement climatique a négativement (positivement) affecté entre $72 \%$ $(5 \%)$ des arbres dans les populations du Sud et $40 \%$ (25\%) dans les arbres du Nord avec des tendances de croissance positives qui ont été favorisées par les températures hivernales et leur abondance étaient inversement corrélée à la productivité forestière.

- Nos résultats ajoutent des preuves de la divergence de croissance des arbres dans le bassin méditerranéen et montrent la transition progressive entre les forêts où les tendances positives (zones tempérées et boréales) et négatives (zone méditerranéenne) de croissance dominent.

\section{INTRODUCTION}

Drought is the main limiting factor for tree growth in the Mediterranean Basin (Specht, 1981) where drought spells are expected to increase (Meehl and Tebaldi, 2004). These changes may lead to higher soil moisture deficits during growing periods and thus alter forest productivity (see Boisvenue and Running, 2006) and change species distribution in many regions (Lenoir et al., 2008). Mediterranean climate [defined by the characteristic summer drought] has been migrating northwards since $10000 \mathrm{BP}$ with the corresponding change in the dominating vegetation type from deciduous tree communities to the current sclerophyllous forests (Jalut et al., 1997). Therefore, as the present climatic change episode involves

\footnotetext{
*Corresponding author:dmartin@inia.es; dmartinbenito@gmail.com
} 
temperature warming, there might be a similar South-North progression of both the change and its effects on vegetation.

The Mediterranean basin and its mountain regions are highly sensitive to impacts of global warming (Allen, 2003). Seasonal rainfall distribution along the western Mediterranean has high intra- and inter-annual variability, which have increased together with autumn dryness during the last decades (González-Hidalgo et al., 2001; Rodrigo et al., 1999). However, these trends and their effects on forest growth seem to have an important local component probably caused by regional conditions, such as the abrupt and complex topography (Barbéro et al., 1998).

Around the Mediterranean basin, some studies show decreasing radial growth trends for different tree species during the second half of the 20th century (Macias et al., 2006; Piovesan et al., 2008; Sarris et al., 2007) while others show growth enhancement during the same period (Martínez-Vilalta et al., 2008; Touchan et al., 2005; Vila et al., 2008). For example, in north-eastern Spain Scots pine (Pinus sylvestris L.) shows positive growth trends mainly on wetter sites (MartínezVilalta et al., 2008) whereas in France the opposite is true for both Aleppo (Pinus halepensis Mill.) and Scots pines (Vila et al., 2008).

In several regions of the world, different trees within the same forests show decreasing and increasing growth trends. In central Italy, Piovesan et al. (2008) reported a decreasing trend in the majority of beech (Fagus sylvatica L.) individuals although other individuals showed increasing trends. Similar results have been found for the northern tree line in North America (Pisaric et al., 2007; Wilmking et al., 2004). In Mediterranean forests, global warming further increases the already high water stress which would reduce tree growth (Macias et al., 2006; Piovesan et al., 2008; Sarris et al., 2007). However, some studies have suggested the rising $\mathrm{CO}_{2}$ concentration as an explanation of a possible growth increase of trees in dry temperate climates (Knapp et al., 2001; MartínezVilalta et al., 2008). $\mathrm{CO}_{2}$-induced increase of water-use efficiency (WUE) would be more evident at sites with greater stress and more severely limiting resources (e.g. Idso and Idso, 1994) which also influence forest productivity.

Black pine (Pinus nigra Arn.) is widely distributed along the Mediterranean basin. In the western part, black pine forests are commonly found in an intermediate altitudinal belt between the more thermophilic pines at lower altitudes (Pinus halepensis Mill., P. pinea L., $P$. pinaster Ait.), and the more mesic pines at higher altitudes ( $P$. sylvestris L.), and as mixed forests in the transitions zones (Barbéro et al., 1998). In the Iberian Peninsula, black pine is distributed along the eastern mountain ranges and covers a wide latitudinal gradient. These forests have been greatly affected by climate change during the second half of 20th century (Andreu et al., 2007). These facts place black pine in an intermediate position between boreal locations, in which mainly positive growth trends have been detected (Martínez-Vilalta et al., 2008), and more xeric pines, where negative trends dominate (Sarris et al., 2007). Therefore black pine is an interesting species to study the effects of climate change on tree growth.
An analysis of the spatiotemporal growth trends and response to climate in black pine populations can increase our knowledge of the progression of consequences of global change on vegetation. In our study, black pine tree rings are analyzed in order to: (a) examine the climatic signal in treering chronologies and analyze their temporal variability and long-term trends; (b) test whether the effect of climate forcing on tree growth has been changing; and (c) investigate the possible occurrence of differences in growth trends among black pine populations and trees within populations growing in the eastern mountains of the Iberian Peninsula.

\section{MATERIAL AND METHODS}

\subsection{Study areas}

Our four study areas were located in four mountain ranges in the eastern part of the Iberian Peninsula [from North to South, "Tortosa" (TRT), "Teruel" (TER), "Serranía de Cuenca" (CUE) and "Sierra de Cazorla" (SCA)]. In our ca. $500 \mathrm{~km}$ transect, latitude ranged from $37.86^{\circ}$ to $40.73^{\circ} \mathrm{N}$ and from $3.01^{\circ} \mathrm{W}$ to $0.22^{\circ} \mathrm{E}$ in longitude, and the elevation of the sites from 1100 to $1470 \mathrm{~m}$ a.s.l. (Fig. 1). The slope ranged from flat to $30^{\circ}$, and at most sites slope was intermediate to steep. The regions CUE and SCA were divided into two subregions each (Ser and Pal, and Sil and Czl, respectively).

These forests were commonly managed through the shelterwood technique. The 20 permanent sample plots (PSP) in which our trees were sampled were established by the Spanish National Institute of Agricultural Research (INIA) in 1964 covering the natural distribution area of black pine in Spain. The PSPs were inventoried at 5- to 9-y intervals from 1964 to 2006 (see Martin-Benito et al., 2008b, for details on PSP characteristics and inventory information).

\subsection{Climate data}

Data of mean temperatures $\left({ }^{\circ} \mathrm{C}\right)$ and total monthly precipitation $(\mathrm{mm})$ were provided by the Spanish Meteorological Agency (AEMET) from several meteorological stations (Fig. 1) located not further than $35 \mathrm{~km}$ from chronology sites. To avoid effects caused by inter-stations differences in data length and quality, we used homogenized precipitation datasets developed for the period 1899-1999 by Gónzalez-Rouco et al. (2001) to which AEMET data for 2000-2006 was added. The temperature datasets was shortest in SCA (19402006) but reached the end of the 19th century or beginning of 20th century in the other three regions. We also considered the use of homogenised and adjusted temperature data created for many Spanish meteorological stations (Brunet et al., 2006). Unfortunately, none of these stations were close to our sampling sites and preliminary results showed lower correlations with tree-ring chronologies. However, we were able to detect inhomogeneities in our temperature data for TER before 1905 and thus we discarded data prior to that year.

\subsection{Dendroecological approach}

In each PSP, two cores were taken at breast-height from 15-16 dominant trees and a total of 293 trees were used. In order to avoid compression wood, cores were taken at approximately a right angle 


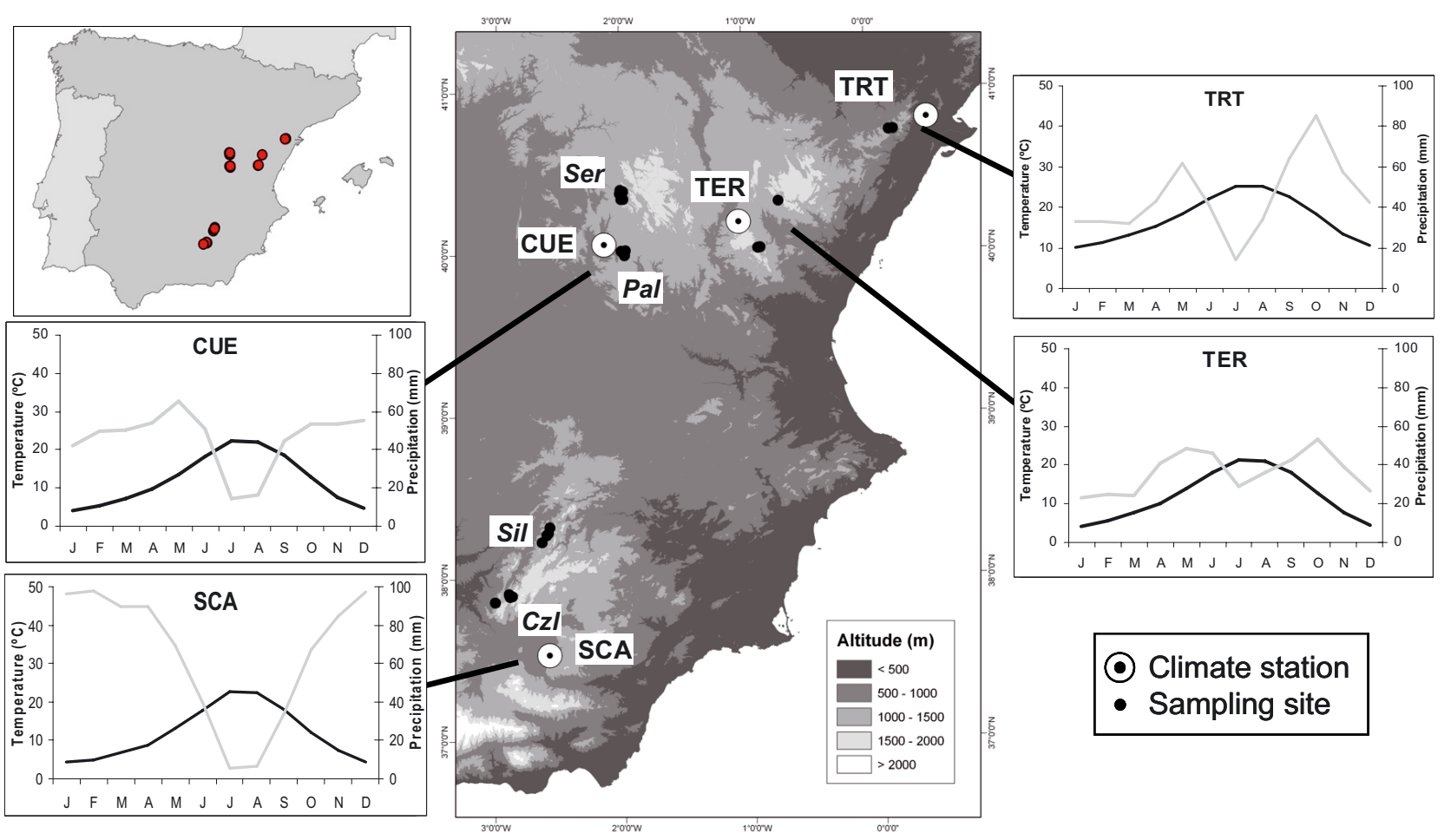

Figure 1. Location of study sites and climate stations. Climate features expressed by Gaussen diagrams: monthly temperatures (black line; left axis) and precipitation (grey line; right axis) calculated for the period 1940-2005.

from the slope. Cores were mounted on grooved boards and sanded. Total ring width (TRW) was measured to the nearest $0.01 \mathrm{~mm}$ with a measuring table and the software TSAP (Rinn, 2003).

Raw TRW series were visually and statistically crossdated with TSAP (Rinn, 2003) by the Gleichläufigkeit (measures the year-toyear agreement between the interval trends of two chronologies, based upon the sign of agreement and expressed as percentage), $t$-values (determines the correlation between curves) and the crossdate index (CDI) which is a combination of both. In addition, COFECHA (Grissino-Mayer, 2001) was used to assure accuracy of crossdating and measurement.

To remove the age trend from the cross-dated ring width series (Fritts, 1976), individual series were detrendend with a negative exponential curve or a straight line and standard chronologies were obtained with ARSTAN (Cook, 1985). Dimensionless tree-ring width indexes (TRWI) were computed by dividing the observed raw ringwidth value by the value of the fitted exponential curve. Standard chronologies (autocorrelation not removed) are more suited for longterm trend analysis because low frequency variability might be removed from chronologies along with autocorrelation (Cook, 1985) and because our objective was to show the relationship between growth and climate variables of several months and not to use that relationship to reconstruct any climate variables (Wilmking et al., 2004). Therefore, standard chronologies were used to assess climategrowth relationships as well as their stationarity and consistency. Composite chronologies were obtained by pooling together all treering width series from the same region or sub-region using a robust estimation of the mean to reduce the influence of outliers (Cook, 1985).

\subsubsection{Analysis}

Several dendrochronological statistics were calculated with ARSTAN (Cook, 1985) and COFECHA (Grissino-Mayer, 2001). Mean sensitivity (MS) measures the relative difference from one tree-ring to the next and thus the year to year variation, first order autocorrelation coefficients (AC) reflects how previous year growth influences current year growth, and mean interseries correlation (Rbar) measures the between-tree signal (Fritts, 1976). We also analyzed the variation of our chronologies and the change of the importance of climatic influence on growth (Tardif et al., 2003) by calculating their MS using a 40 -y time window lagged $5 \mathrm{y}$. The average $\left(\mathrm{MS}_{x}\right)$ and standard deviation $\left(\mathrm{SD}_{x}\right)$ of the mean sensitivity of all chronologies were calculated to show general trends. In addition, to assure regional chronologies correctly portrayed the theoretically perfect chronology, expressed population signal (EPS; Wigley et al., 1984) was calculated using 40-y moving windows lagged $5 \mathrm{y}$.

\subsubsection{Climate growth relationships}

Climate-growth correlations for the common period 1940-2005 were calculated between regional or subregional chronologies and monthly total precipitation and mean temperature between July of the previous year to September of the current year with DENDROCLIM2002 (Biondi and Waikul, 2004). Bootstrapped confidence intervals were calculated for these correlations (Guiot, 1991). The stability of climate growth relationship was assessed by moving correlation functions (MCF) calculated between climate data and regional chronologies for periods of $50 \mathrm{y}$ moved along the time series. 

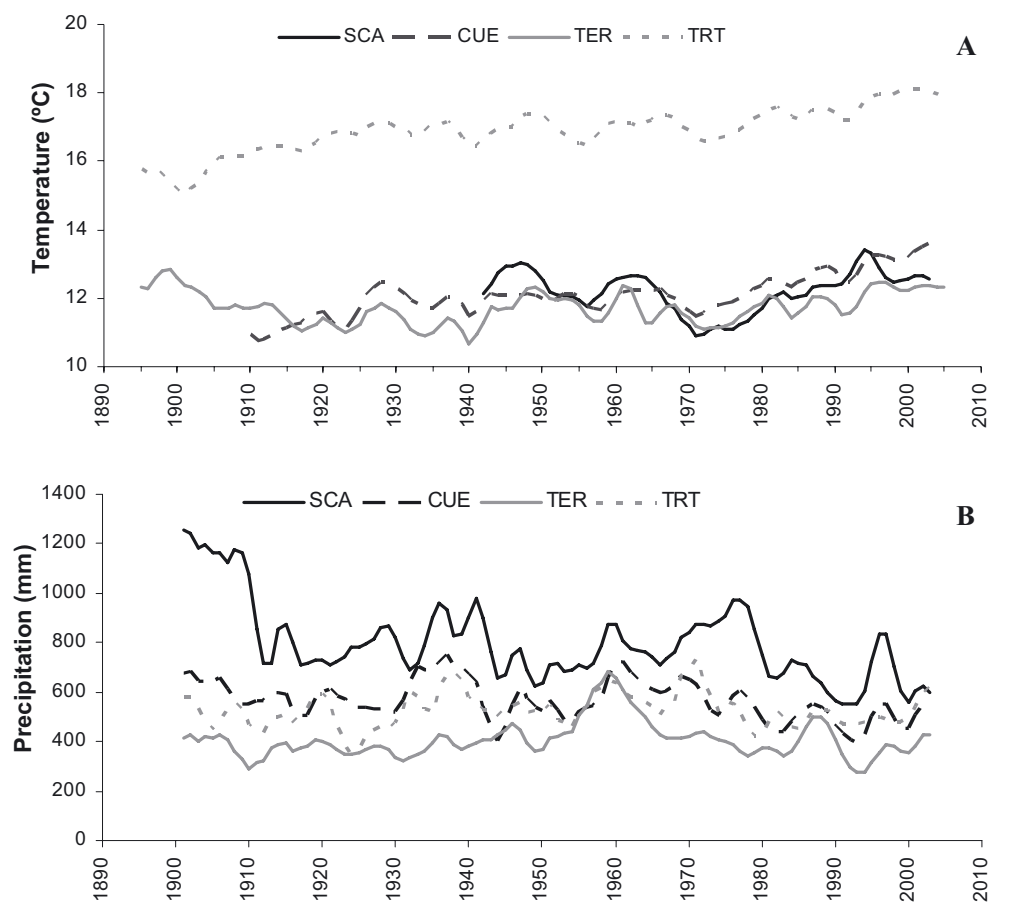

Figure 2. Mean annual temperature (A) and precipitation (B) of the four meteorological stations used (5-y low pass filter applied). $r$ Values for time trends of temperatures, (i) all periods available: SCA $(0.05)$, CUE $(0.81 *)$, TER $\left(0.48^{*}\right)$, TRT $\left(0.85^{*}\right)$; (ii) the period 1973-2005: SCA $\left(0.89^{*}\right)$, CUE $(0.97 *)$, TER $\left(0.86^{*}\right)$, TRT $(0.92 *)$. $r$ Values for time trends of precipitations, (i) all periods available: SCA ( $\left.-0.58^{*}\right)$, CUE $(-0.42 *)$, TER $(-0.10)$, TRT $(0.09)$; (ii) the period $1960-2005$ : SCA $(-0.60 *)$, CUE $(-0.73 *)$, TER $(-0.58 *)$, TRT $(-0.44 *)$. ${ }^{*}$ Significant at $p<0.05$.

This time window, $50 \mathrm{y}$, was used because it was long enough to be less dependent on extreme events but short enough to allow the use of the shortest climate dataset (67 $\mathrm{y}$ in SCA).

\subsubsection{Analysis of growth trends}

In order to analyze growth trends, we visually classified trees in three groups according to the growth trend shown by their standard chronologies. Trees that showed a steady trend (increase or decrease) from any year to the end of the period were referred to as "positive" and "negative trenders" respectively (Piovesan et al., 2008; Pisaric et al., 2007). Trees in which two cores showed opposite trends (probably the result of compression wood) or that had no obvious trend were referred to as "neutral trenders". Average chronologies of "positive" and "negative trenders" from each region (TRT, TER, CUE, and SCA) were used for further analysis. We ensured the quality of these tree group chronologies by recalculating the EPS (Wigley et al., 1984). Although this procedure might be observer biased, it has been successfully used before (e.g. Graumlich, 1999). It is important to note that in every region there were trees from different ages in each of the three groups (Tab. II). In order to check whether these divergent trends could be caused by productivity differences at the intraplot level (in the range of meters), we calculated a site index for each individual positive and negative trender using the dominant-height growth model in Martín-Benito et al. (2008b).

We explored the possibility of climate forcing in these divergent trends. First, climate-growth relationships were recalculated with positive and negative trenders' regional chronologies as explained before. Second, we examined the consistency of growth responses through time for all climate variables but focused on those that produced the highest correlations with chronologies and which differed most between positive and negative trenders by region. We explored the common lower frequency variations (i.e. removing interannual tree-ring and climate variability) between climate and standard chronologies by applying a low pass filter of $5 \mathrm{y}$ to both data (e.g. Briffa et al., 1998; Carrer and Urbinati, 2006). The strength of these relationships was assessed by linear regression considering two periods: before and after 1973. This break-point was chosen (1) because after 1973 mean annual temperature increases in our meteorological observations (see Results; Fig. 2); and (2) to obtain two time periods of equal length of the shortest climate dataset (SCA, 1940-2005). Prior to this lower frequency analysis we checked that the unfiltered standard chronologies and climate variables were significantly correlated for both subperiods (results not shown).

We also analyzed the relationship between site productivity and percentage of "positive trenders" per region. Here we used site index (defined as the average height of the 100 trees with the largest diameter per hectare; Assmann, 1970) at the age of $80 \mathrm{y}$ developed for the same plots used in this study (Martín-Benito et al., 2008b) as a measure of site productivity.

Inventory data from PSP allowed us to check changes in density and other stand dynamics phenomena in all our plots. Because PSP belong to different forests and regions, and because the plot ages (plots are even-aged) are very different, there was no inter- or intra-regional temporal synchronicity of cuts and/or thinnings. Nevertheless, we checked the proportion of positive and negative trenders against plot density changes between any combinations of two 
inventories that occurred in all plots to assure that the observed trends were not caused by them (results not shown).

\section{RESULTS}

\subsection{Analysis of climate data}

Annual mean temperature in the study areas show clear increases during the last decades (Fig. 2A). Three meteorological stations (CUE, TER, and TRT) showed significant increases during the entire period of available records (linear regression slopes of $0.019{ }^{\circ} \mathrm{C} \cdot \mathrm{y}^{-1}, 0.007{ }^{\circ} \mathrm{C} \cdot \mathrm{y}^{-1}$, and $0.016{ }^{\circ} \mathrm{C} \cdot \mathrm{y}^{-1}$, respectively). Furthermore, a "break point" in all four records was observed around 1973 after which climate warming accelerated. When the period 1973-2005 was considered, all stations displayed significant $(p<0.001)$ increases in annual temperatures between $0.033{ }^{\circ} \mathrm{C} \cdot \mathrm{y}^{-1}$ (TER) and $0.057^{\circ} \mathrm{C} \cdot \mathrm{y}^{-1}$ (CUE).

Considering annual precipitation (Fig. 2B), SCA $(r=$ $-0.58 ; p<0.05)$ and CUE $(r=-0.424 ; p<0.05)$ were the only regions to show a significant decrease during the entire available period (1899-2005). However, we observed that after the year 1960 total annual precipitation decreased significantly in all regions $(p<0.05)$. However, comparison of the means before and after the year 1960 (periods 1899-1959 and 1960-2006) did not yield significant differences for any of the regions because of the large inter-annual variations. Among the study areas (Fig. 1), total annual precipitation decreased from south (SCA; $777 \mathrm{~mm} \cdot \mathrm{y}^{-1}$ ) to north (TER; $434 \mathrm{~mm} \cdot \mathrm{y}^{-1}$ ).

\subsection{Chronology statistics}

Our tree-ring chronologies shared a common period 19142006 for all regions, except for SCA where the end (sampling) year was 2005. Statistical characteristics of the raw ring width chronologies (Tab. I) showed that mean sensitivity was higher in TER (0.39) and lower in Sil (0.26) while the first order autocorrelation coefficients were lower in TER (0.70) and higher in $\operatorname{Ser}(0.78)$. The moving EPS function showed values $>0.85$ (commonly used threshold value for climate-growth relationships; Wigley et al., 1984) in all regions for the common period. These statistics suggest that our chronologies are well suited for examining the relationship between climatic variability and tree growth.

Average mean sensitivity $\left(\mathrm{MS}_{x}\right)$ for all regional tree-ring chronologies continuously increased $\left(R^{2}=0.91 ; p<0.001\right)$ while the $\mathrm{MS}_{x}$ standard deviation $\left(\mathrm{SD}_{x}\right)$ followed a similar but weaker increase $\left(R^{2}=0.45 ; p<0.05\right)$ with a sharp rise at the end of the period (Fig. 3).

\subsection{Temporal variability in radial growth}

The majority of trees in our regions had a clear decrease in TRWI during the last $30 \mathrm{y}$, except in TER where most trees were negative or neutral trenders. Percentages of negative trenders ranged from $36.7 \%$ in TER to $72.2 \%$ in SCA of all sampled trees in a region (Tab. II). Neutral trenders were more abundant in TER (43.3\%) followed by CUE (35.7\%) and TRT $(34 \%)$. However, we found positive trenders in all the regions accounting from $25 \%$ of all trees in TRT to $3 \%$ of trees in Sil. As expected from the applied procedure, positive and negative trenders showed similar high and low frequency variation during most of the chronology length but the final divergence between TRWI of negative and positive trenders appeared around 1987 in SCA and between 1993 and 1995 in the other three regions (Fig. 4).

The percentages of positive trenders in each plot was negatively correlated with forest site productivity $\left(R^{2}=0.37\right.$; $p<0.005$; Fig. 5) suggesting that the least productive stands had higher percentages of positive trenders. Productivity was also related to latitude because the least productive plots were in the north (Fig. 5) where the driest regions were located (Fig. 1). Thus the percentage of positive trenders also showed a relationship with latitude.

Negative and positive trenders' chronologies were reliable for the analyses of climate-growth interactions as their EPS values were $>0.85$ (except for CUE positive trenders whose EPS values were $>0.80$ ). Using the PSP inventory data, we found no relationship between stand density changes (trees $\cdot \mathrm{ha}^{-1}$ or $\%$ of trees) in PSPs prior to the start of growth divergence and proportion of positive trenders in each plot. Intra-plot differences of site index were non significant for any of the plots (results not shown).

\subsection{Climate growth relationships}

We calculated correlation functions between climatic variables and regional or sub-regional chronologies. Because correlation functions were similar for the two sub-regions in SCA and the two in CUE, regional chronologies were used for further climate-growth analysis. Tree growth in the four regions was primarily affected by two major climatic factors: the negative effect of summer temperature and the positive effect of spring-summer precipitation (Fig. 6). However, some differences were evident between regions with a latitudinal component. Summer months in which temperature affected growth changed from June, in the southernmost region (SCA), to June-August, in CUE, and July-August in the north (TER and TRT). A similar north-south gradient applied for spring precipitation as the influential months were May-June in SCA and CUE and June-July in TRT. In this case TER was an exception with higher response to March and May precipitation. The effect of previous year precipitation decreased from south to north (Fig. 6). Mean monthly temperature of previous autumn (August to October) negatively affected tree growth whereas those of previous winter (December to February) enhanced it.

Results of moving correlation functions (MCF) showed that the relationship between growth and summer temperatures increased during the second half of the 20th century, particularly in CUE and TER (Fig. 7). Correlations with spring-summer 

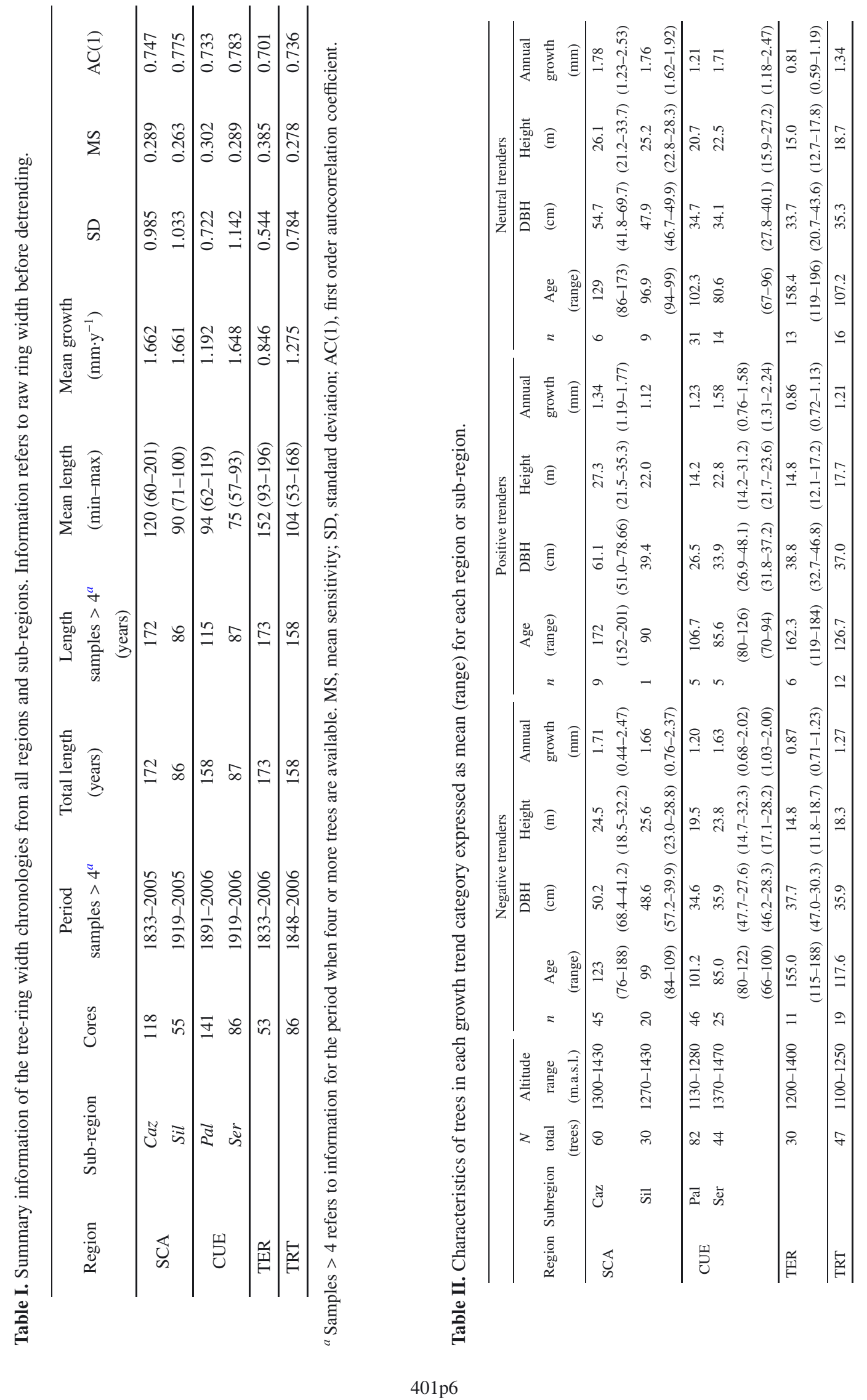


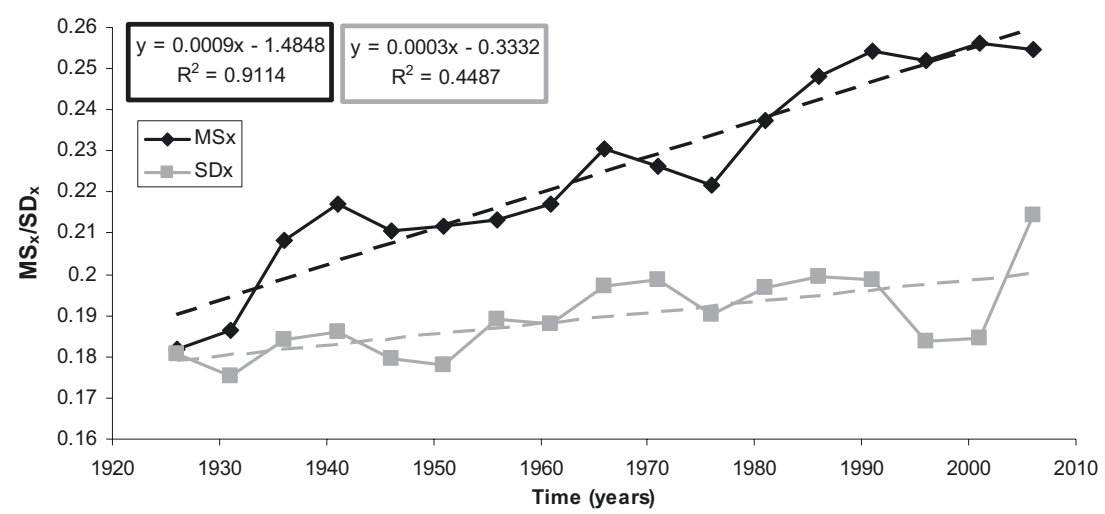

Figure 3. Temporal trend of the mean sensitivity of all sub-regional chronologies $\left(\mathrm{Ms}_{x}\right.$; black line) and the standard deviation of the mean sensitivity ( $\mathrm{SD}_{x}$; grey line) calculated for intervals of $40 \mathrm{y}$ lagged $5 \mathrm{y}$.

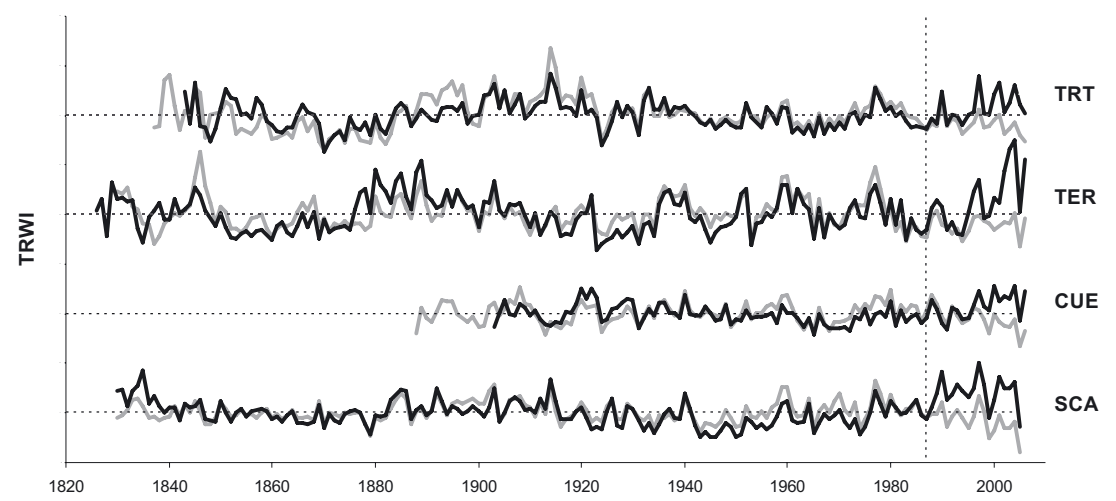

Figure 4. Comparison of mean standardized tree-ring width index of negative (grey lines) and positive trenders (black lines) for the four regions analysed. Dashed line marks year 1987 when the divergence between negative and positive trenders' chronologies starts in SCA. Divergence in other regions starts in later years.

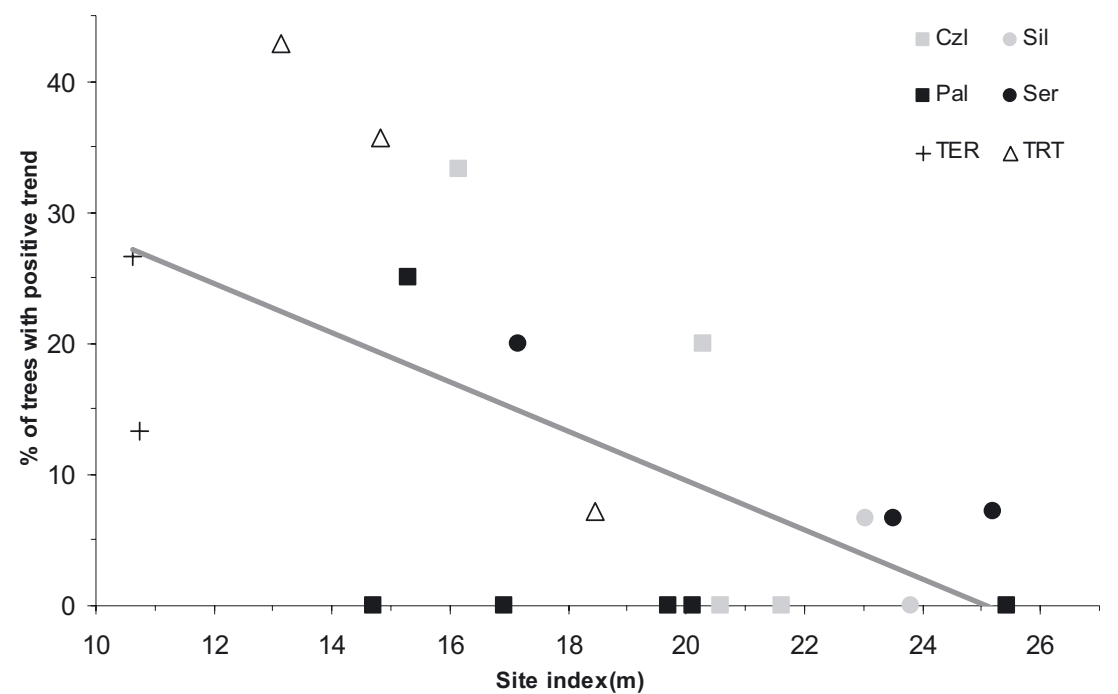

Figure 5. Percentage of trees with positive growth trends against site index for each plot. Correlation calculated for all the plots $(r=0.61$, $p<0.005$ ). Mean site index is calculated as the average of the site index (height of the 100 trees with largest diameters per hectare) in each plot. 

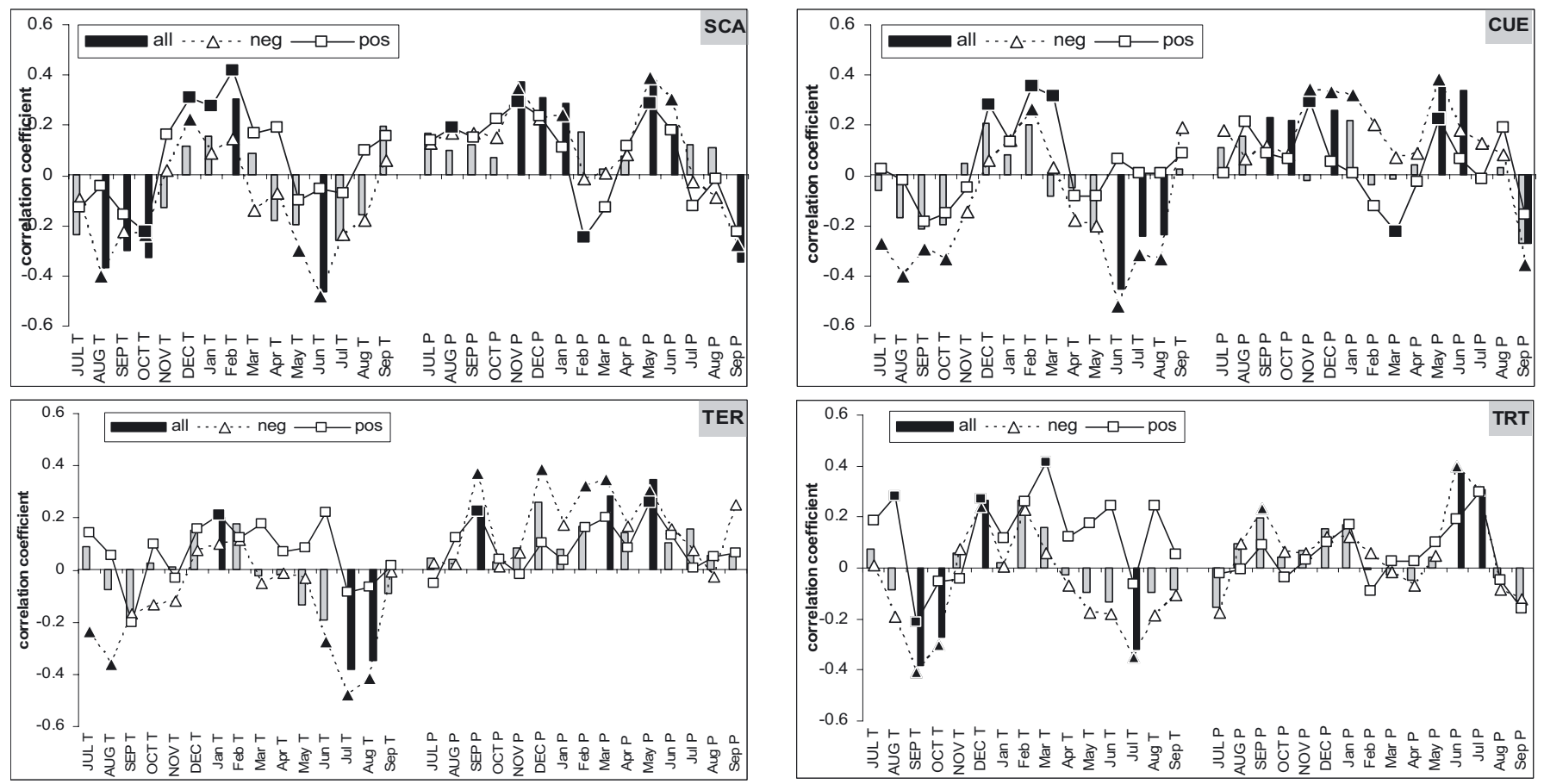

Figure 6. Correlation coefficients between mean monthly temperature $(T)$ and total month precipitation $(P)$ and standard tree-ring width indexes with complete chronologies (bars) of negative (neg; triangles) and positive (pos; squares) trenders in each region (period 1940-2005). Climate variables with capital letters correspond to the year previous to tree-ring formation. Black bars and solid symbols: $95 \%$ bootstrapped significant values.

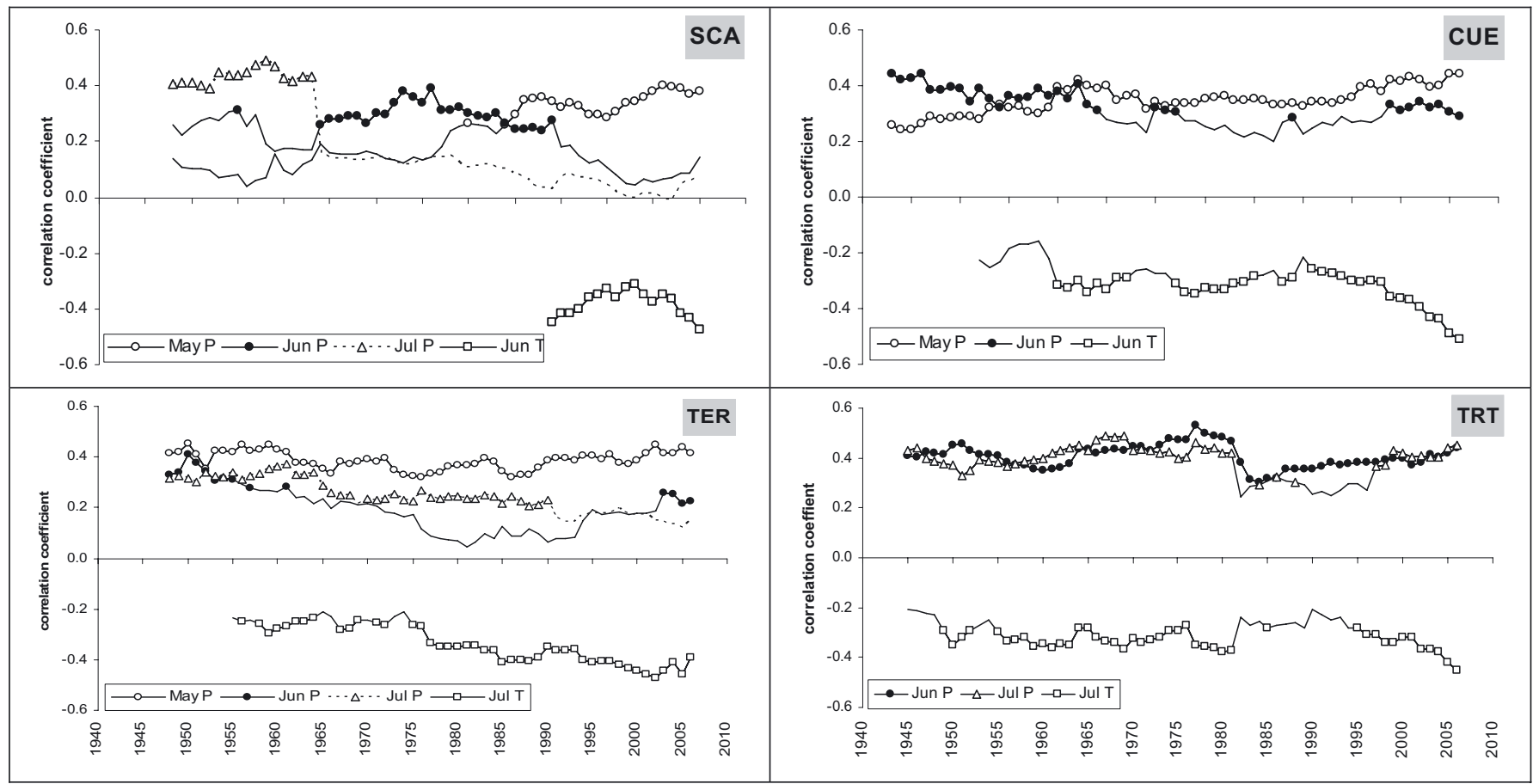

Figure 7. Moving correlation function (MCF) of SCA, CUE, TER, and TRT standard tree-ring indexes from complete chronologies from each region with selected climate variables ( $T$, temperature; $P$, precipitation). Each point corresponds to the end of a 50-y interval. Symbols represent significant correlation coefficients with $95 \%$ bootstrapped confidence intervals. 
precipitations also increased and interestingly a temporal trend in the months that affect growth the most was evidenced. In SCA, the effect of July precipitation was significant at the beginning of the 1900s but gradually lost significance; then June precipitation became significant around the middle of last century. Later, May became the only significant month. In the other three regions a similar change was also observed for May, June, and July precipitations in such a way that it was clear that the stronger correlations were displaced to earlier months in the year (Fig. 7).

\subsection{Patterns of growth response to climate between negative and positive trenders}

The major differences in the responses of growth to climate between positive and negative trenders were found in summer temperatures (Fig. 6). In all regions, negative trenders showed high negative correlations with June, July and/or August mean monthly temperatures while positive trenders seemed almost irresponsive to these variables. Positive trenders showed stronger positive correlations with winter temperatures (Fig. 6), especially in the two southernmost regions (SCA and CUE). Differences in correlations with precipitation between the two groups of trees showed smaller differences. Therefore we focused our analyses on the effects of winter temperatures prior to growth and current year summer.

The low pass-filtered chronologies of negative trenders in each region closely followed their most influential climate variable, summer temperatures of June (SCA and CUE) or July (TER and TRT) (Fig. 8). These negative relationships intensified in all cases after the "break point" of 1973. Winter temperature and growth of positive trenders were also closely related, although in SCA and CUE this relationship was only significant after 1973 (Fig. 8). Correlation between growth of positive trenders and temperatures of December and February before growth in TRT changed from negative $(r=-0.45$; $p<0.008)$ before 1973 to positive $(r=0.57 ; p<0.001)$ after that year.

\section{DISCUSSION}

\subsection{Relationship between climate and radial growth}

Our finding of highly significant relationships between tree radial growth of the majority of black pine and summer temperature (negative) and hydrological year (September to June) cumulative precipitation (positive) is consistent with previous results for the Mediterranean (Andreu et al., 2007; Macias et al., 2006; Sarris et al., 2007) and for the same species in other parts of Europe (Leal et al., 2008; Lebourgeois, 2000). Although in our study these relationships were observed along the latitudinal range in the Iberian Peninsula, intra-annual differences were also observed between regions (i.e. the progression of different months being significant for each region). Significant temperatures in SCA (south) were lagged 1-2 months ahead of TER and TRT (north) as in other latitudinal transects (e.g. Hofgaard et al., 1999).

Precipitation between autumn and spring seems especially crucial for black pine growth (Fig. 6). Warm season precipitation correlations with growth was delayed from mainly May in SCA to June-July in TRT indicating that the signal of moisture stress progressed from south to north. Precipitation becomes more limiting as latitude decreases (Woodward, 1987) as shown for SCA which depends more on precipitation than northern regions despite having the highest mean annual precipitation (most likely caused by the higher seasonality).

During the last century, a spatiotemporal change of the months whose climate variables are influential for growth was also evident. Our results show a trend in which the influence of summer months decreased while that of spring months increased following a south-north progression (Fig. 7). This fact would evidence that the effects of global change on black pine growth started in the southern regions and later advanced towards the north.

The relationship between growth and precipitation during the cool season is closely affected by spring-summer temperature controlling the soil moisture balance (e.g. MartínezVilalta et al., 2008). The increasing negative (positive) relationship with the mean temperature of spring-summer months (autumn to spring precipitation) (Fig. 7) suggests that moisture stress has increased in all regions, in accordance with results for most of the Mediterranean (Andreu et al., 2007; Macias et al., 2006; Piovesan et al., 2008) and parts of North America (Biondi, 2000). The significant upward trend of the mean sensitivity of tree-ring chronologies (Fig. 3) provides additional evidence (Andreu et al., 2007; Macias et al., 2006). This higher moisture stress is caused by an increase in mean annual temperatures and reduced precipitation after the mid 20th century, consistent with previous studies (Rodrigo et al., 1999).

\subsection{Radial growth trends and their climatic drivers}

The negative effect of increasing temperatures on growth (Fig. 8) is in accordance with tree growth decline caused by decreasing precipitation or warming temperatures observed along the Mediterranean (Jump et al., 2006a; Macias et al., 2006; Peñuelas et al., 2008; Piovesan et al., 2008; Sarris et al., 2007). Despite the general negative long-term trend of radial growth, analysis of individual black pine tree-ring series revealed two groups of trees with distinct growth patterns during the second half of the 20th century. Positive trenders were observed in all regions. In SCA divergence starts around 1987 while in other regions it occurs after 1994 (Fig. 4), suggesting a south-north latitudinal advance of this effect similar to that found for the influence of monthly climate variables (see above).

Consistent with Brunet et al. (2006), we found 1973 the start year of accelerated warming in Spain and used it as a break point for sub-period comparisons. After that year, positive and negative trenders exhibit different responses to climate in all regions (Fig. 6). Negative trenders were increasingly and negatively affected by warm summers after 1973, similar to the 

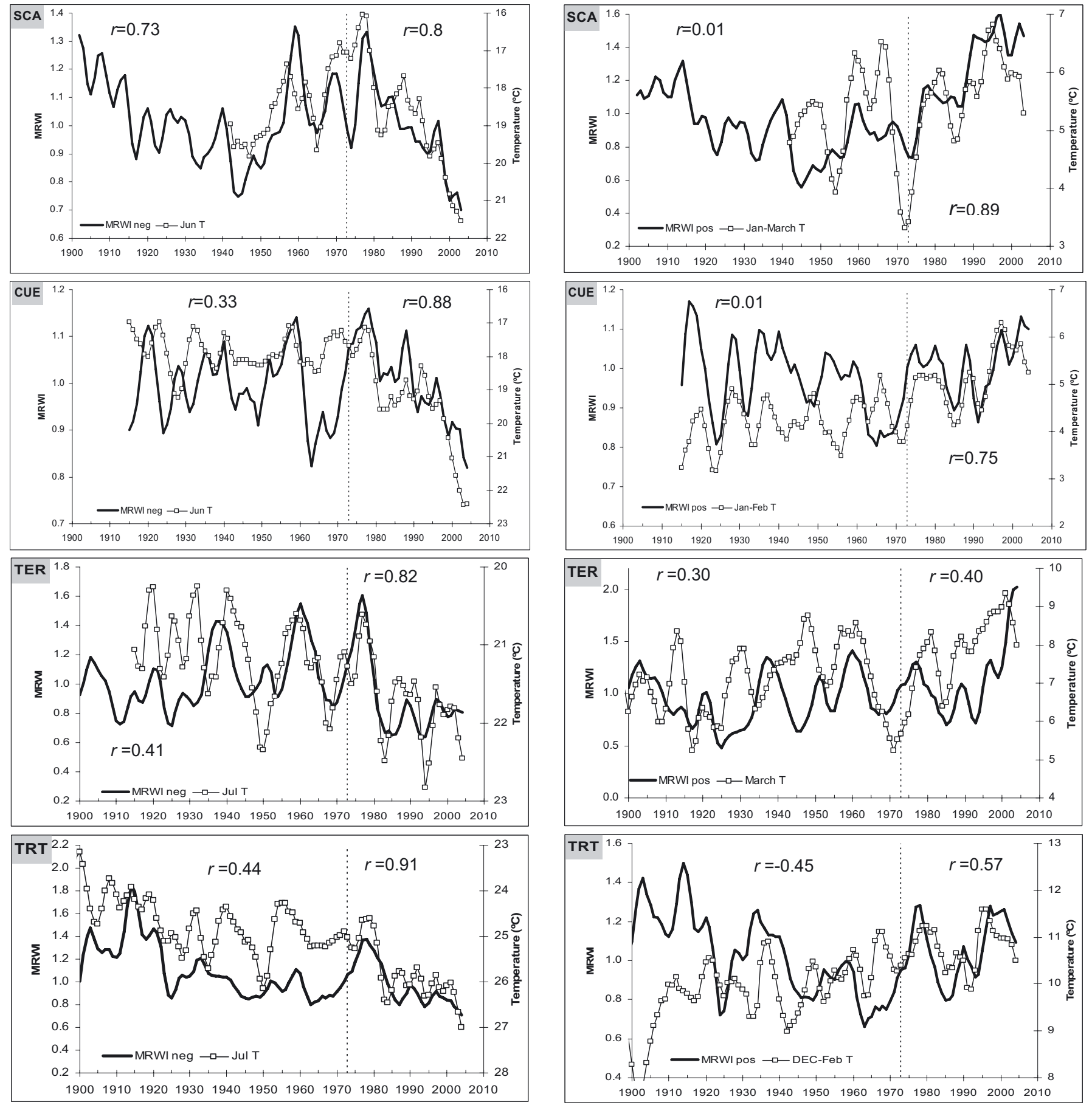

Figure 8. Relationship between mean ring width index of negative (MRWI neg; left) and positive (MRWI pos; right) trenders and selected monthly temperature variables. Note the inverted $y$ axis for temperature on the left hand side graphics. Data series have been smoothed with a 5-y low pass filter. Vertical line marks the year 1973, considered as "break point" for inter-period comparisons. 
response of complete regional chronologies. Growth of positive trenders seems not to be negatively influenced by summer temperatures. In all regions, positive trenders were positively affected by warmer winters in accordance with the response of other Mediterranean flora (Peñuelas et al., 2004) probably caused by increased winter photosynthesis and carbohydrates accumulation (Lebourgeois, 2000) which increase earlywood width (Martín-Benito et al., 2008a).

These results suggest that global change might cause divergent tree growth in different ecosystems such as Mediterranean (Llorens et al., 2004) and boreal conifer forests (for a review see D'Arrigo et al., 2008) although climate-site interactions may play an important role. Most positive growth responses to temperature have been observed in climates where low temperature is the main factor limiting growth (D'Arrigo et al., 2004; Pisaric et al., 2007; Wilmking et al., 2004), whereas negative trends mainly appear in warmer climates where precipitation and high temperatures are limiting (e.g. Macias et al., 2006; Peñuelas et al., 2008; Sarris et al., 2007). The individual analysis of trees in our regions (located between those with these two major trends) allowed us to document the gradual latitudinal progression of divergence and the relative proportion of positive trenders. These proportions ranged from $5 \%$ to $25 \%$ of all trees at any given region, suggesting that they reflect sub-population differences and not effects caused by only a few individuals (Pisaric et al., 2007).

In dry climates, several acclimation mechanisms such as $\mathrm{CO}_{2}$-induced increase in WUE may be in effect (e.g. Llorens et al., 2004). The fact that the ratio of positive trenders were inversely correlated with site productivity and latitude (Fig. 5) agrees with previous studies suggesting that the effect of rising $\mathrm{CO}_{2}$ concentration would be higher in arid sites (Idso and Idso, 1994; Knapp et al., 2001; Soulé and Knapp, 2006) because the increase in WUE would reduce the drought stress of plants (Morison, 1993), although studies in trees are not conclusive (e.g. Jacoby and D'Arrigo, 1997; Kienast and Luxmoore, 1988; Körner et al., 2005). Furthermore, an improvement of WUE caused by increasing $\mathrm{CO}_{2}$ concentration has already been suggested in black pine in the Austrian Alps (Leal et al., 2008) and for other species in the Mediterranean (MartínezVilalta et al., 2008; Rathgeber et al., 2000) and North America (Knapp et al., 2001). Rathgeber et al. (2000) suggested that a combination of warming winters and double $\mathrm{CO}_{2}$ concentrations enhanced net primary productivity of $P$. halepensis stands, in accordance with our results of positive trenders. Because we detected no relationship between changes in stand density or micro-site differences and proportion of positive trenders, stand dynamics might be ruled out as a possible cause. However, other factors such as nitrogen depositions or a combination of these and other unknown factors (Kienast and Luxmoore, 1988) cannot be neglected.

In this same respect, SCA and CUE had the lowest share of positive trenders suggesting that the fastest growing trees (higher SI and mean annual growth; Tab. II) are most limited by increasing summer warmth and drought stress (Barber et al., 2000). Most likely, improvement of WUE (if any) cannot compensate for the increase in temperatures and decrease in precipitation in SCA and CUE as shown for other species such as Scots pine (Martínez-Vilalta et al., 2008) and beech (Jump et al., 2006a; Peñuelas et al., 2008) in their southern distribution ranges.

The observed pattern of positive and negative trenders might also reflect the adaptive plasticity of a species with high intrapopulation genetic variability (Nikolic and Tucic, 1983) and its influence on tree diameter growth. Some individual trees might be acclimating in situ to new climatic conditions (e.g. Jump et al., 2006b) that could render them more competitive and/or profit from the decline or death of other trees in the stand. Black pine populations in southern Spain have lower intra-population genetic diversity (MartínAlbertos and Gonzalez-Martínez, 2000) and are genetically isolated from populations further north (Afzal-Rafii and Dodd, 2007), supporting the higher similarity between individual tree growth patterns in SCA. A synergistic effect of genetic diversity and WUE increase might also be in progress because the differential responses of growth to increasing $\mathrm{CO}_{2}$ concentration have an important genetic determinant within species (Beerling et al., 1996).

\section{CONCLUSIONS}

Along our latitudinal transect, warming temperature and decreasing precipitation have increased the already high soil water stress, which in turn is the most probable cause of the observed forest growth decline. Because of these climate changes, tree-growth relationships with its main climatic drivers are not stable along time. The dependency of tree growth on precipitation has increased in the last century and drought has experienced an upward shift after 1950's. Despite the general growth decline observed, our findings provide evidence of contrasting growth responses within the same forest stands. Previously observed in some Mediterranean species (Piovesan et al., 2008) and boreal forests (Pisaric et al., 2007; Wilmking et al., 2004), these divergent phenomena might also appear in species which have experienced broad forest decline (e.g. Macias et al., 2006; Peñuelas et al., 2008; Sarris et al., 2007), and thus be more general than previously thought. The latitudinal progression of the radial growth decline and proportion of positive trenders strongly support the rapid northward advance of Mediterranean climate caused by global change and its effect on tree ecology and growth.

Acknowledgements: We gratefully acknowledge Andrés BravoOviedo, Enrique Garriga, and Ricardo Ruíz-Peinado for assisting in field data collection and sampling. Ignacio Barbeito and Guillermo Gea-Izquierdo, and two anonymous reviewers provided helpful comments that greatly improved the manuscript. We thank the Spanish Meteorological Agency (AEMET) for providing climate data. This research was supported by Instituto Nacional de Investigaciones Agrarias y Alimentarias (INIA) through a doctoral grant to D. MartínBenito and funds to Research Project OT03-002.

\section{REFERENCES}

Afzal-Rafii Z. and Dodd R.S., 2007. Chloroplast DNA supports a hypothesis of glacial refugia over postglacial recolonization in disjunct 
populations of black pine (Pinus nigra) in western Europe. Mol. Ecol. 16: 723-736.

Allen H.D., 2003. Response of past and present Mediterranean ecosystems to environmental change. Prog. Phys. Geogr. 27: 359-377.

Andreu L., Gutierrez E., Macias M., Ribas M., Bosch O., and Camarero J.J., 2007. Climate increases regional tree-growth variability in Iberian pine forests. Glob. Chang. Biol. 13: 1-12.

Assmann E., 1970. The principles of forest yield study. Pergamon Press Ltd., Oxford, $506 \mathrm{p}$.

Barber V.A., Juday G.P., and Finney B.P., 2000. Reduced growth of Alaskan white spruce in the twentieth century from temperatureinduced drought stress. Nature 405: 668-673.

Barbéro M., Losiel R., Queézel P., Richardson D.M., and Romane F., 1998. Pines of the Mediterranean Basin. In: Richardson D.M. (Ed.), Ecology and biogeography of Pinus, Cambridge University Press, Cambridge.

Beerling D.J., Heath J., Woodward F.I., and Mansfield T.A., 1996. Drought- $\mathrm{CO}_{2}$ interactions in trees: observations and mechanisms. New Phytol. 235-242.

Biondi F., 2000. Are climate-tree growth relationships changing in northcentral Idaho? Arct. Antarct. Alp. Res. 32: 111-116.

Biondi F. and Waikul K., 2004. DENDROCLIM2002: A $\mathrm{C}^{++}$program for statistical calibration of climate signals in tree-ring chronologies. Computers Geosci. 30: 303-311.

Boisvenue C. and Running S.W., 2006. Impacts of climate change on natural forest productivity - Evidence since the middle of the 20th century. Glob. Chang. Biol. 12: 1-21.

Briffa K.R., Schweingruber F.H., Jones P., Osborn T.J., Shiyatov S.G., and Vaganov E.A., 1998. Reduced sensitivity of recent tree-growth to temperature at high northern latitudes. Nature 391: 678-682.

Brunet M., Saladié O., Jones P., Sigró J., Aguilar E., Moberg A., Lister D., Alexander W., López D., and Almarza C., 2006. The development of a new dataset of Spanish daily adjusted temperature series (SDATS) (1850-2003). Int. J. Climatol. 26: 1777-1802.

Carrer M. and Urbinati C., 2006. Long-term change in the sensitivity of tree-ring growth to climate forcing of Larix decidua. New Phytol. 170: 861-872.

Cook E.R., 1985. A time series analysis approach to tree-ring standardization. University of Arizona, Arizona, Tucson, p. 171.

D’ Arrigo R.D., Kaufmann R.K., Davi N., Jacoby G.C., Laskowski C., Myneni R.B., and Cherubini P., 2004. Thresholds for warminginduced growth decline at elevational tree line in the Yukon Territory, Canada. Global Biogeochem. Cycles 18: GB3021.

D'Arrigo R.D., Wilson R., Liepert B., and Cherubini P., 2008. On the "Divergence problem" in northern forests: A review of the tree-ring evidence and possible causes. Glob. Planet. Change 2003 60: 289305.

Fritts H.C., 1976. Tree rings and Climate. Blackburn Press, Caldwell, New Jersey, 567 p.

González-Hidalgo J.C., Luis M.D., Raventós, J., and Sánchez, J.R., 2001. Spatial distribution of seasonal rainfall trends in a western Mediterranean area. Int. J. Climatol. 21: 843-860.

González-Rouco J.F., Jiménez J.L., Quesada V., and Valero F., 2001. Quality control and homogeneity of precipitation data in the southwest of Europe. J. Clim. 14: 964-978

Graumlich L.J., 1999. Subalpine tree growth, climate, and increasing $\mathrm{CO}_{2}$ : an assessment of recent growth trends. Ecology 72: 1-11.

Grissino-Mayer H.D., 2001. Evaluating crossdating accuracy: a manual and tutorial for the computer program COFECHA. Tree-Ring Res. 57: 205-221.

Guiot J., 1991. The bootstrapped response method. Tree-ring Bull. 51: $39-41$.
Hofgaard A., Tardif J., and Bergeron Y., 1999. Dendroclimatic response of Picea mariana and Pinus banksiana along a latitudinal gradient in the eastern Canadian boreal forest. Can. J. For. Res. 29: 1333-1346.

Idso K.E. and Idso S.B., 1994. Plant responses to atmospheric $\mathrm{CO}_{2}$ enrichment in the face of environmental constraints: a review of the past 10 years' research. Agric. For. Meteorol. 69: 153-2003.

Jacoby G.C. and D'Arrigo R.D., 1997. Tree rings, carbon dioxide, and climatic change. Proc. Natl. Acad. Sci. USA 94: 8350-8353.

Jalut G., Amat A.E., Mora S.R.I., Fontugne M., Mook R., Bonnet L., and Gauquelin T., 1997. Holocene climatic changes in the western Mediterranean: installation of the Mediterranean climate C. R. Acad. Sci. Ser. II A Earth Planet. Sci. 325: 327-334

Jump A.S., Hunt J.M., and Peñuelas J., 2006a. Rapid climate changerelated growth decline at the southern range edge of Fagus sylvatica. Global Change Biol. 12: 2163-2174.

Jump A.S., Hunt J.M., Peñuelas J., and Martínez-Izquierdo J.A., 2006b. Natural selection and climate change: temperature-linked spatial and temporal trends in gene frequency in Fagus sylvatica. Mol. Ecol. 15: 3469-3480.

Kienast F. and Luxmoore R.J., 1988. Tree-ring analysis and conifer growth responses to increased atmospheric $\mathrm{CO}_{2}$ levels. Oecologia 76: 487-495.

Knapp P.A., Soulé P.T., and Grissino-Mayer H.D., 2001. Detecting potential regional effects of increased atmospheric $\mathrm{CO}_{2}$ on growth rates of western juniper. Glob. Chang. Biol. 7: 903-917.

Körner C., Asshoff R., Bignucolo O., Hättenschwiler S., Keel S.G., Peláez-Riedl S., Pepin S., Siegwolf R.T.W., and Zotz G., 2005. Carbon flux and growth in mature deciduous forest trees exposed to elevated $\mathrm{CO}_{2}$. Science 309: 1360-1362.

Leal S., Emaus D., Grabner M., Wimmer R., and Cherubini P., 2008. Tree rings of Pinus nigra from the Vienna basin region (Austria) show evidence of change in climatic sensitivity in the late 20th century. Can. J. For. Res. 38: 744-759.

Lebourgeois F., 2000. Climatic signals in earlywood, latewood and total ring width of Corsican pine from western France. Ann. For. Sci. 57: $155-164$.

Lenoir J., Gégout J.C., Marquet P.A., Ruffray P.D., and Brisse H., 2008. A significant upward shift in plant species optimum elevation during the 20th century. Science 320: 1768-1771.

Llorens L., Penuelas J., Estiarte M., and Bruna P., 2004. Contrasting growth changes in two dominant species of a Mediterranean shrubland submitted to experimental drought and warming. Ann. Bot. Lond. 94: 843-853.

Macias M., Andreu L., Bosch O., Camarero J.J., and Gutiérrez E., 2006. Increasing aridity is enhancing silver fir (Abies alba Mill.) water stress in its south-Western distribution limit. Clim. Change 79: 289313.

Martín-Albertos S. and Gonzalez-Martínez S.C., 2000. Conservación de recursos genéticos de coníferas en España. Investig. Agrar. Sist. Recur. Forest. Fuera de serie 2: 151-183.

Martín-Benito D., Cherubini P., del Río M., and Cañellas I., 2008a. Growth response to climate and drought in Pinus nigra Arn. trees of different crown classes. Trees 22: 363-373.

Martín-Benito D., Gea-Izquierdo G., del Río M., and Cañellas I., 2008b. Long-term trends in dominant-height growth of black pine using dynamic models. For. Ecol. Manage. 256: 1230-1238.

Martínez-Vilalta J., López B.C., Adell N., Badiella L., and Ninyerola M., 2008. Twentieth century increase of Scots pine radial growth in NE Spain shows strong climate interactions. Glob. Chang. Biol. 14: $1868-2881$.

Meehl G.A. and Tebaldi C., 2004. More Intense, more frequent, and longer lasting heat waves in the 21st century. Science 305(5686): 994-997. 
Morison J.I.L., 1993. Response of plants to $\mathrm{CO}_{2}$ under water limited conditions. Plant Ecol. 104/105: 193-209.

Nikolic D. and Tucic N., 1983. Isoenzyme variation within and among populations of European black pine (Pinus nigra Arnold). Silvae Genet. 32(3/4): 80-89.

Peñuelas J., Gordon C., Llorens L., Nielsen T., Tietema A., Beier C., Bruna P., Emmett B., Estiarte M., and Gorissen A., 2004. Nonintrusive field experiments show different plant responses to warming and drought among sites, seasons, and species in a NorthSouth European gradient. Ecosystems 7: 598-612.

Peñuelas J., Hunt J.M., Ogaya R., and Jump A.S., 2008. Twentieth century changes of tree-ring $\delta^{13} \mathrm{C}$ at the southern range-edge of Fagus sylvatica: increasing water-use efficiency does not avoid the growth decline induced by warming at low altitudes. Glob. Chang. Biol. 14: 1076-1088.

Piovesan G., Biondi F., Di Filippo A., Alessandrini A., and Maugeri M., 2008. Drought-driven growth reduction in old beech (Fagus sylvatica) forests of the central Apennines, Italy. Glob. Chang. Biol. 14: $1265-1281$.

Pisaric M.F.J., Carey S.K., Kokelj S.V., and Youngblut D., 2007. Anomalous 20th century tree growth, Mackenzie Delta, Northwest Territories, Canada. Geophys. Res. Lett. 34: L05714.

Rathgeber C., Nicault A., Guiot J., Keller T., Guibal F., and Roche P., 2000. Simulated responses of Pinus halepensis forest productivity to climatic change and $\mathrm{CO}$ increase using a statistical model. Glob. Planet. Change 26: 405-421.

Rinn F., 2003. TSAP-Win professional, Time series analysis and presentation for dendrochronology and related applications. Version 0.3 , Quick Reference, Frank Rinn, Heidelberg, Germany, 20 p.

Rodrigo F.S., Esteban-Parra M.J., Pozo-Vazquez D., and Castro-Diez Y., 1999. A 500-year precipitation record in Southern Spain. Int. J. Climatol. 9: 1233-1253.
Sarris D., Christodoulakis D., and Körner C., 2007. Recent decline in precipitation and tree growth in the eastern Mediterranean. Global Change Biol. 13: 1187-1200.

Soulé P.T. and Knapp P.A., 2006. Radial growth rate increases in naturally occurring ponderosa pine trees: a late-20th century $\mathrm{CO}_{2}$ fertilization effect? New Phytol. 171: 379-390.

Specht R.L., 1981. Primary production in Mediterranean climate ecosystems regenerating after fire. In: Di Castri F., Goodall D.W. and Specht R.L. (Eds.), Mediterranean-type shrublands, Elsevier, Amsterdam.

Tardif J., Camarero J.J., Ribas M., and Gutiérrez E., 2003. Spatiotemporal variability in tree growth in the central Pyrenees climatic and site influences. Ecol. Monogr. 73: 241-257.

Touchan R., Xoplaki E., Funkhouser G., Luterbacher J., Hughes M.K., Erkan N., Akkemik Ü., and Stephan J., 2005. Reconstructions of spring/summer precipitation for the Eastern Mediterranean from tree-ring widths and its connection to large-scale atmospheric circulation. Clim. Dyn. 25: 75-98.

Vila B., Vennetier M., Ripert C., Chandioux O., Liang E., Guibal F., and Torre F., 2008. Has global change induced divergent trends in radial growth of Pinus sylvestris and Pinus halepensis at their bioclimatic limit? The example of the Sainte-Baume forest (south-east France). Ann. For. Sci. 65: 709.

Wigley T.M.L., Briffa K.R., and Jones P.D., 1984. On the average value of correlated time series, with applications in dendroclimatology and hydrometeorology. J. Appl. Meteor. 23: 201-213.

Wilmking M., Juday G.P., Barber V.A., and Zald H.S.J., 2004. Recent climate warming forces opposite growth responses of white spruce at treeline in Alaska through temperature thresholds. Glob. Chang. Biol. 10: 1724-1736.

Woodward F.I., 1987. Climate and plant distribution. Cambridge University Press, Cambridge. 